\title{
Variability Russian Rice Varieties in Essential Amino Acids Composition
}

\author{
Yulia Goncharova ${ }^{1,3, *}$, Svetlana Verechagina ${ }^{1}$, Nikolay Ochkas ${ }^{1,3}$, and Sergey Goncharov ${ }^{2}$ \\ ${ }^{1}$ Federal Research Center for Rice, 350921 Krasnodar, Belozerny 3, Russia \\ ${ }^{2}$ Kuban State Agrarian University, 350000 Krasnodar, Russia \\ 3"Aratai" LTD, "Skolkovo", 143026 Moscow, Russia
}

\begin{abstract}
Rice contains antioxidants, minerals, carbohydrates, lipids, vitamins that make it a functional food. A dozen times higher content of antioxidants was noted in black-grain and red-grain rice varieties as compared to white-grain ones. In terms of protein content, color and whitegrain varieties do not differ significantly. The protein composition largely determines the nutritional value and functional properties, as well as the texture and taste of rice. Although rice contains less protein than many cereals, its biological value is highest due to balanced composition of amino acids. Nutritional value of different rice varieties varies greatly due to different amino acid composition. Determination of amino acid composition was carried out on devices Kapel 105 - M. In the work used 50 collection samples of rice. The variability was studied and the sources were identified among domestic rice varieties. To create a new generation varieties with more balanced amino acid composition, it is necessary both to isolate sources with a high content of individual amino acids, and varieties with high characteristics in terms of content complex of amino acids, especially essential ones.
\end{abstract}

\section{Introduction}

Rice contains antioxidants, minerals, carbohydrates, lipids, vitamins, which make it a functional food product [1,2]. A dozen times higher content of antioxidants was noted in black-grain and red-grain rice varieties as compared to white-grain ones. Colored and white-grain varieties do not differ significantly in protein content [3]. The protein composition also largely determines the nutritional value and functional properties, as well as the texture and taste characteristics of rice [4]. Although rice contains less protein than many grains, its biological value is highest due to the balanced composition of amino acids. The nutritional value of different varieties of rice varies greatly, due different amino acid composition [5].

Amino acids are building material for creating proteins, their deficiency disrupts synthesis of vitamins, pigments, hormones. Their unbalanced composition in food products weakens cognitive abilities, reduces immunity. Relationship with likelihood of diabetes has been established for several amino acids serine, alanine, arginine. Lysine content, amino

\footnotetext{
* Corresponding author: yuliya_goncharova_20@mail.ru
} 
acid limiting the digestibility of protein in cereals, is higher in rice than in wheat, maize and sorghum [6]. The variability of rice varieties has been established for content following amino acids: aspartic, glutamic, serine, glycine, alanine, leucine, and proline [5]. Rice protein is rich in glutamic, aspartic acids, alanine and glycine [7]. The amino acid composition is associated with the organoleptic characteristics of product and the unique taste characteristic of rice varieties in dishes [8].

Among the studied varieties, the content of leucine and valine, alanine, glycine was the highest in the varieties of local selection (ancient). It is calculated that the consumption of $100 \mathrm{~g}$ of rice three times a day provides the daily requirement for valine and many other essential amino acids, their number is different for rice varieties, on average 4-5 [9-10].

At the same time, there are reports of relationship between the content of asparagine together with soluble sugars with the formation of acrylamide, a carcinogenic substance [11]. The main groups of products in which acrylamide is formed are named: french fries and chips, coffee, biscuits, confectionery and bakery products. Acrylamide accumulates as a result of the interaction of asparagine with sugars (glucose and fructose) at temperatures above $120^{\circ} \mathrm{C}$ and low humidity. An interesting fact is that the amount of asparagine in wheat varies from 75.5 to $2150 \mathrm{mg} / \mathrm{kg}$, in oats from 51 to $1390 \mathrm{mg} / \mathrm{kg}$, in corn from 71 to $2900 \mathrm{mg} / \mathrm{kg}$, in rye from 310 to $900 \mathrm{mg} / \mathrm{kg}$ and in rice from 14.9 to $24.9 \mathrm{mg} / \mathrm{kg}$. That is, on average, the amount of asparagine in rice is 3 times less than in wheat and corn and 2 times less than in oats [12]. This property is used by adding rice flour to baked goods and confectionery [13] to reduce the carcinogenicity of the above hazardous products. However, the revealed varietal variability according to the trait makes it possible to further increase the usefulness of products with rice flour [14].

The delivery of essential amino acids, which are not synthesized in animals, is especially important; their set is different for different organisms. Amino acids irreplaceable for humans: tryptophan, phenylalanine, isoleucine, valine, methionine, threonine, leucine, lysine. Arginine is classified as conditionally irreplaceable, histidine synthesis is reduced in children and patients [15-16].

The aim of our work was to study the variability of the amino acid composition of Russian rice varieties.

\section{Methods and conditions of work}

In this work, we used both collection samples and promising and approved varieties of rice. Plants were grown in vessels on optimal background of mineral nutrition $\left(\mathrm{N}_{120} \mathrm{P}_{60} \mathrm{~K}_{60}\right)$, the plant density was 10 plants per vessel. The Flagman cultivar with the same planting density served as a control. With a lack of plants or their death, a marker with purple leaves was planted. Determination of the amino acid composition was carried out on Kapel 105 - M. devices. Material from 20 plants of each sample was taken for analysis. The amount of amino acids in rice samples was expressed as a percentage per sample volume.

\section{Results and discussion}

Chromatogram amino acid composition Krepysh rice sample obtained in the MultiChrom program is shown in Figure 1. Analysis of variance showed reliability of differences in amino acid composition of samples (Table 1). 
Table 1. Analysis of variance for reliability of differences in composition of amino acids

\begin{tabular}{|c|c|c|c|c|c|}
\hline Amino acid & SS Effect & df & MS Effect & F & p \\
\hline Asparagine, \% & 6947,41 & 37,00 & 187,77 & 2253,22 & 0,00 \\
\hline Proline, \% & 2518,73 & 37,00 & 68,07 & 811,48 & 0,00 \\
\hline Arginine,\% & 1061,02 & 37,00 & 28,68 & 339,53 & 0,00 \\
\hline Tyrosine,\% & 280,12 & 37,00 & 7,57 & 87,12 & 0,00 \\
\hline b-phenylalanine, \% & 1589,94 & 37,00 & 42,97 & 505,27 & 0,00 \\
\hline Leucine,\% & 4135,50 & 37,00 & 111,77 & 1323,36 & 0,00 \\
\hline Methionine,\% & 7076,27 & 37,00 & 191,25 & 2279,81 & 0,00 \\
\hline Valine,\% & 1805,88 & 37,00 & 48,81 & 581,81 & 0,00 \\
\hline Threonine,\% & 5321,80 & 37,00 & 143,83 & 1725,99 & 0,00 \\
\hline Serine,\% & 5159,21 & 37,00 & 139,44 & 1639,57 & 0,00 \\
\hline a-alanine, \% & 5380,66 & 37,00 & 145,42 & 1733,52 & 0,00 \\
\hline Glycine,\% & 2086,84 & 37,00 & 56,40 & 663,18 & 0,00 \\
\hline Glutamine,\% & 1953,97 & 37,00 & 52,81 & 607,68 & 0,00 \\
\hline Cysteine,\% & 1533,36 & 37,00 & 41,44 & 473,30 & 0,00 \\
\hline
\end{tabular}

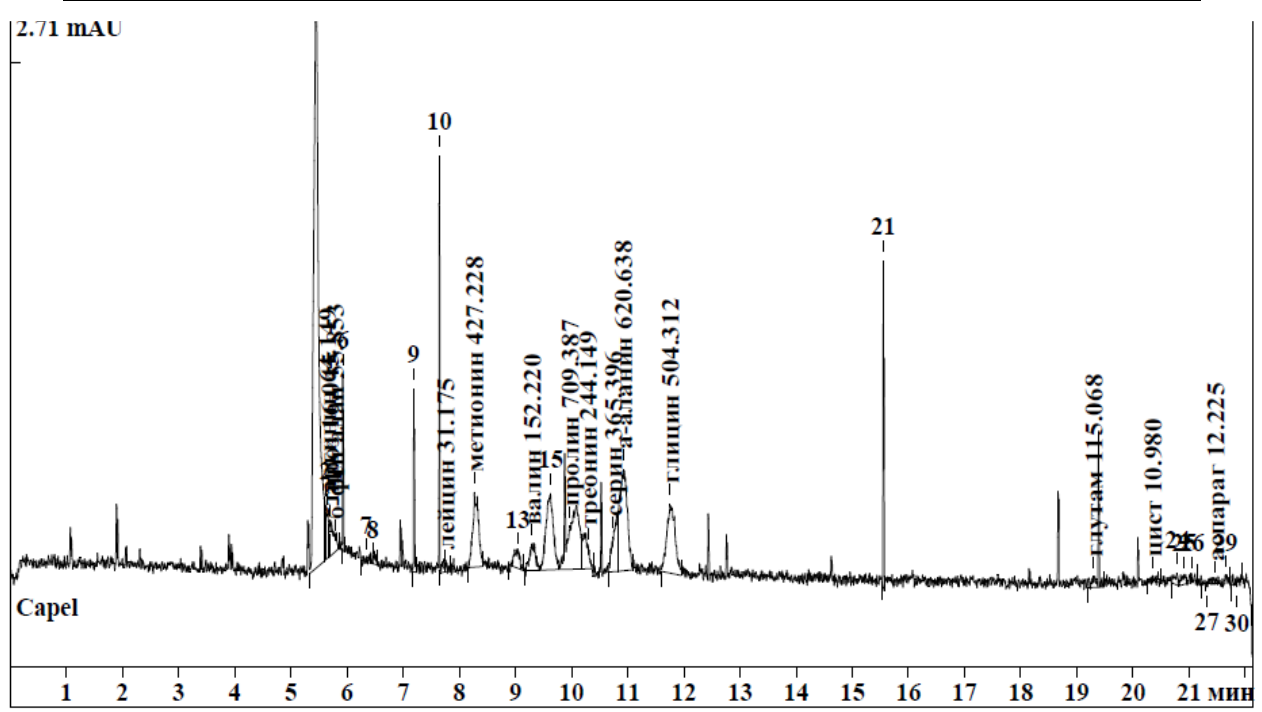

Fig. 1. Chromatogram obtained in the MultiChrom program for Windows (C) 1993-2002 Ampersand Ltd. amino acid composition Krepysh rice sample.

The range of variation of domestic rice samples in the composition of amino acids is presented in Table 2. 
Table 2. The range variation samples in composition of amino acids

\begin{tabular}{|c|c|c|c|c|}
\hline Amino acid & Average & Minimum & Maximum & $\begin{array}{c}\text { Standard } \\
\text { deviation }\end{array}$ \\
\hline Asparagine, $\%$ & 21,89 & 5,40 & 37,77 & 0,73 \\
\hline Proline, $\%$ & 4,45 & 0,55 & 22,76 & 0,45 \\
\hline Arginine, $\%$ & 1,91 & 0,03 & 19,11 & 0,29 \\
\hline Tyrosine, $\%$ & 1,68 & 0,4 & 7,07 & 0,16 \\
\hline b-phenylalanine, $\%$ & 3,60 & 0,01 & 14,57 & 0,36 \\
\hline Leucine, $\%$ & 9,63 & 0,56 & 24,84 & 0,58 \\
\hline Methionine, $\%$ & 11,47 & 0,09 & 31,37 & 0,75 \\
\hline Valine, $\%$ & 7,59 & 0,81 & 15,98 & 0,38 \\
\hline Threonine, $\%$ & 11,13 & 0,51 & 31,51 & 0,64 \\
\hline Serine, $\%$ & 10,67 & 0,11 & 21,97 & 0,65 \\
\hline a-alanine, $\%$ & 9,49 & 0,22 & 22,79 & 0,65 \\
\hline Glycine, $\%$ & 3,89 & 0,54 & 17,21 & 0,41 \\
\hline Glutamine, $\%$ & 3,70 & 0,39 & 18,59 & 0,41 \\
\hline Cysteine, $\%$ & 2,94 & 0,22 & 16,29 & 0,37 \\
\hline
\end{tabular}

The maximum amount of amino acids in studied rice varieties is proline $21,9 \%$, valine $11,5 \%$, serine $11,7 \%$, alanine $10,7 \%$, methionine $9,6 \%$, glycine $9,4 \%$. The lack of essential amino acids is to some extent compensated nonessential. For example, phenylalanine is replaced by tyrosine, methionine-homocysteine, arginine-glutamic acid. However, this process requires energy costs.

The variability of Russian samples in composition of irreplaceable amino acids is presented in Table 3.

Table 3. Variability of samples for composition of non-essential amino acids

\begin{tabular}{|c|c|c|c|c|c|c|}
\hline Variety & $\begin{array}{c}\text { Phenylalanine } \\
\%\end{array}$ & $\begin{array}{c}\text { Leucine, } \\
\%\end{array}$ & $\begin{array}{c}\text { Methionine, } \\
\%\end{array}$ & $\begin{array}{c}\text { Valine, } \\
\%\end{array}$ & $\begin{array}{c}\text { Threonine, } \\
\%\end{array}$ & $\begin{array}{c}\text { Arginine, } \\
\%\end{array}$ \\
\hline Leader & 0,60 & 1,42 & $\mathbf{1 4 , 2 0}$ & $\mathbf{1 8 , 4 8}$ & 2,11 & 3,54 \\
\hline Khazar & 1,42 & 4,89 & $\mathbf{2 4 , 5 1}$ & 1,64 & 0,73 & $\mathbf{1 0 , 0 6}$ \\
\hline Kumir & 0,80 & 1,95 & $\mathbf{1 4 , 5 0}$ & 10,72 & 8,07 & 0,84 \\
\hline Anahit & 0,55 & 0,90 & $\mathbf{1 4 , 4 3}$ & $\mathbf{1 2 , 9 8}$ & 3,36 & 0,1 \\
\hline Natasha & 1,77 & 0,32 & 3,81 & 9,34 & 8,97 & $\mathbf{1 6 , 6 3}$ \\
\hline Partner & $\mathbf{2 , 2 0}$ & 6,20 & 12,90 & 9,31 & $\mathbf{1 0 , 6 2}$ & $\mathbf{2 2 , 2 6}$ \\
\hline Sonnet & 0,25 & 0,51 & 3,01 & 7,38 & $\mathbf{1 1 , 2 4}$ & 0,16 \\
\hline Favorite & 0,53 & $\mathbf{5 , 8 6}$ & 18,85 & $\mathbf{1 2 , 4 0}$ & 2,62 & 0,68 \\
\hline Polevik & 0,43 & $\mathbf{8 , 7 2}$ & 6,33 & $\mathbf{1 9 , 3 2}$ & 6,16 & 2,41 \\
\hline Sturdy & 1,85 & 1,11 & 13,00 & 4,74 & 7,50 & 1,93 \\
\hline Caprice & 0,25 & 1,30 & 9,53 & 7,80 & $\mathbf{1 2 , 5 9}$ & 0,52 \\
\hline Moor & 0,25 & 0,25 & $\mathbf{1 4 , 3 2}$ & 6,60 & 9,20 & 0,01 \\
\hline Olymp & 0,35 & 0,22 & $\mathbf{1 4 , 5 4}$ & 8,94 & 7,86 & 0,58 \\
\hline Yuzhny & 0,25 & 0,35 & $\mathbf{1 7 , 5 3}$ & 4,53 & 3,99 & 4 \\
\hline Atlant & 0,60 & 0,50 & 12,10 & 1,18 & 1,94 & 0,07 \\
\hline Ivushka & 0,38 & 0,25 & 10,33 & $\mathbf{1 7 , 1 3}$ & 5,66 & 4,01 \\
\hline Zlata & $\mathbf{2 , 9 4}$ & 1,83 & 9,09 & $\mathbf{1 5 , 0 7}$ & 3,56 & 2,68 \\
\hline Visit & 0,32 & 2,59 & 4,14 & $\mathbf{1 7 , 3 1}$ & 8,03 & 3,72 \\
\hline Orion & 0,90 & 4,35 & 8,34 & $\mathbf{1 6 , 9 3}$ & 9,48 & 0,25 \\
\hline Gamma & $\mathbf{2 , 1 1}$ & 1,28 & 5,37 & 11,57 & $\mathbf{1 4 , 8 0}$ & 3,08 \\
\hline Flagship & $\mathbf{2 , 0 4}$ & $\mathbf{5 , 8 4}$ & 3,90 & 8,38 & 8,69 & 6,43 \\
\hline
\end{tabular}




\begin{tabular}{|c|c|c|c|c|c|c|}
\hline Variety & $\begin{array}{c}\text { Phenylalanine } \\
\%\end{array}$ & $\begin{array}{c}\text { Leucine, } \\
\%\end{array}$ & $\begin{array}{c}\text { Methionine, } \\
\%\end{array}$ & $\begin{array}{c}\text { Valine, } \\
\%\end{array}$ & $\begin{array}{c}\text { Threonine, } \\
\%\end{array}$ & $\begin{array}{c}\text { Arginine, } \\
\%\end{array}$ \\
\hline Source & 1,01 & 1,67 & 2,71 & $\mathbf{1 7 , 0 5}$ & 9,30 & 0,89 \\
\hline Courage & 0,42 & 1,95 & $\mathbf{1 6 , 4 2}$ & 0,21 & $\mathbf{1 2 , 2 2}$ & 4,41 \\
\hline Esaul & 0,54 & $\mathbf{1 4 , 2 4}$ & 8,54 & 10,43 & 2,62 & 1,21 \\
\hline Regul & 1,85 & 0,58 & 8,18 & 8,48 & 1,83 & 3,45 \\
\hline Amber & 0,25 & 0,40 & 4,53 & 7,70 & 9,46 & 3 \\
\hline Svetlana & $\mathbf{3 , 6 3}$ & 2,51 & $\mathbf{1 8 , 8 8}$ & 12,02 & $\mathbf{1 1 , 4 2}$ & $\mathbf{1 0 , 2 7}$ \\
\hline Assol & 1,06 & 12,71 & 3,81 & 7,56 & 9,17 & 2,98 \\
\hline Mulatka & $\mathbf{6 , 7 4}$ & 0,25 & 5,71 & $\mathbf{2 9 , 3 2}$ & 10,69 & 2,63 \\
\hline Grace & 1,38 & 1,12 & 8,35 & $\mathbf{3 1 , 0 4}$ & 10,45 & 8,37 \\
\hline Konstantin & 0,25 & 4,96 & 0,25 & $\mathbf{2 7 , 8 8}$ & 7,03 & 8,98 \\
\hline Day/Night & $\mathbf{3 , 1 7}$ & 6,09 & $\mathbf{1 3 , 5 6}$ & 6,89 & 0,25 & 5,41 \\
\hline Azov & $\mathbf{6 , 5 8}$ & 2,16 & 6,87 & 2,94 & 8,75 & 1,52 \\
\hline Waterfall & $\mathbf{3 , 8 7}$ & 8,97 & 1,97 & 9,56 & $\mathbf{1 5 , 2 3}$ & 5,5 \\
\hline Rain & $\mathbf{3 , 5 6}$ & 6,98 & $\mathbf{2 0 , 5 6}$ & 3,86 & 5,49 & 1,82 \\
\hline Pearl & $\mathbf{2 , 9 6}$ & $\mathbf{1 3 , 2 0}$ & 0,37 & $\mathbf{2 9 , 4 4}$ & 3,48 & 9,5 \\
\hline Birch & 1,16 & 2,07 & 4,00 & 6,03 & $\mathbf{1 5 , 6 5}$ & 3,42 \\
\hline Diamond & 1,91 & 3,03 & 0,25 & 0,25 & 5,79 & 8,02 \\
\hline Mean & 1,68 & 3,60 & 9,63 & 11,47 & 7,59 & 4,4 \\
\hline LSD 05 & 0,17 & 0,63 & 1,03 & 2,69 & 0,52 & 0,16 \\
\hline
\end{tabular}

The intake of a sufficient amount of phenylalanine into the body is very important, since tyrosine is synthesized from this amino acid, and in case of its deficiency, a deficiency of two amino acids will be established. Sample variability in phenylalanine content is shown in Figure 2.

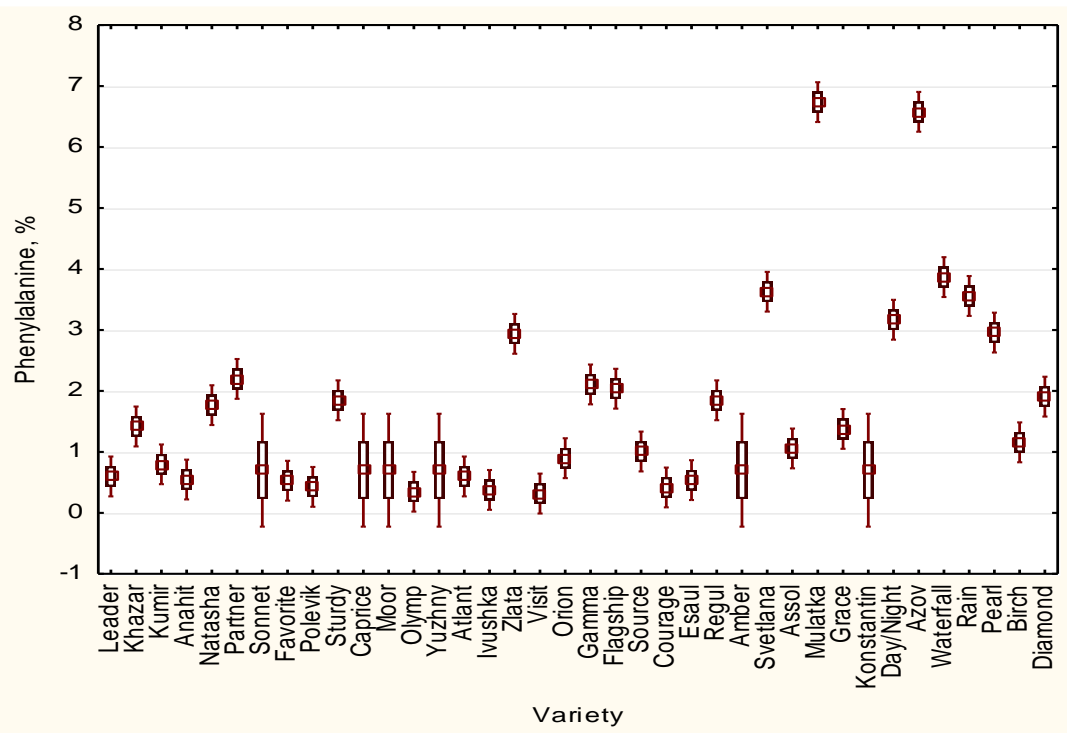

$\square$ Mean
$\square$ Mean \pm SE
$I$ Mean \pm SD

Fig. 2. Variability samples for phenylalanine content

Sources for the content of phenylalanine are varieties: Mulatka, Azov, Day / Night, Waterfall, Rain, Pearl, Svetlana, Zlata.

The variability of domestic samples by groups by the content of methionine and threonine is shown in Figures 3-4. The following varieties are characterized by a high content of methionine: Leader, Khazar, Kumir, Anahit, Mavr Olymp, Yuzhny, Courage, 
Svetlana, Dozhik; threonine: Birch, Waterfall, Gamma, Caprice, Svetlana, Sonnet. Sources of high content of leucine of the variety are also highlighted: Favorit, Polevik, Flagman, Esaul, Zhemchuzhina.

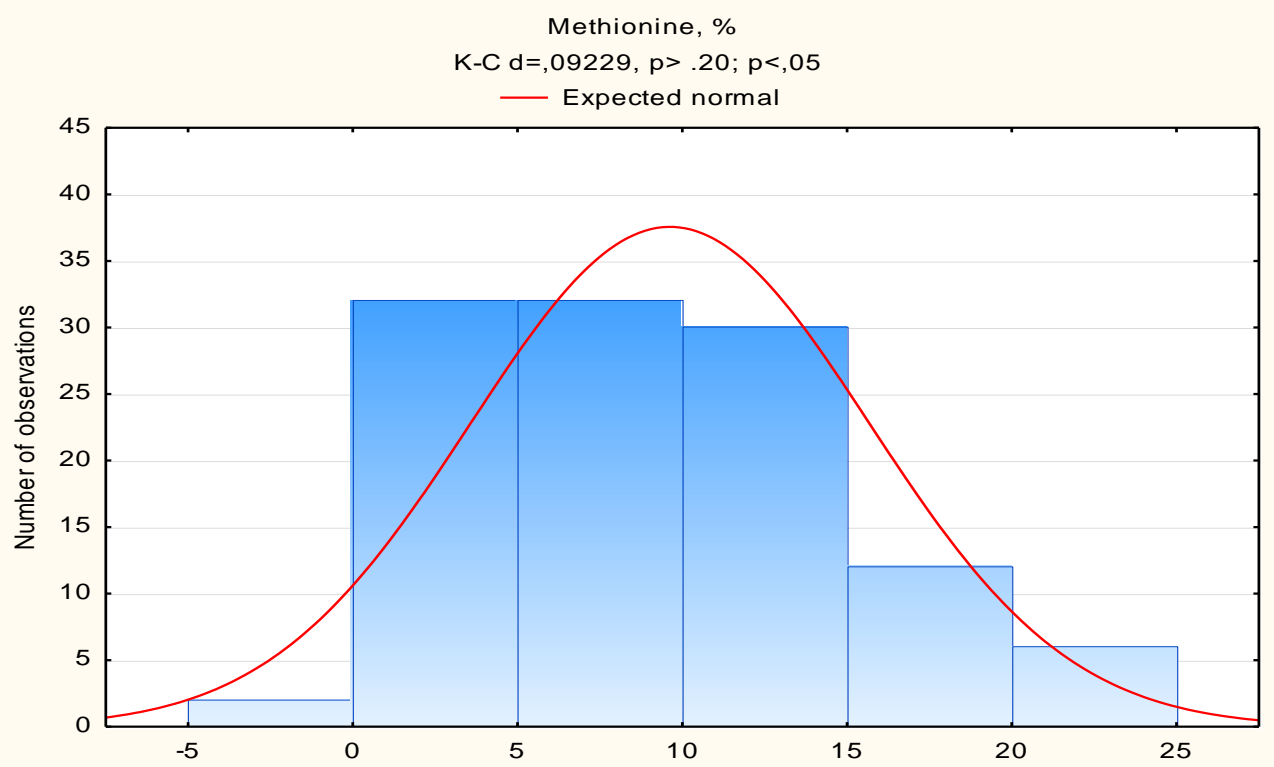

Fig. 3. Distribution samples by groups methionine content

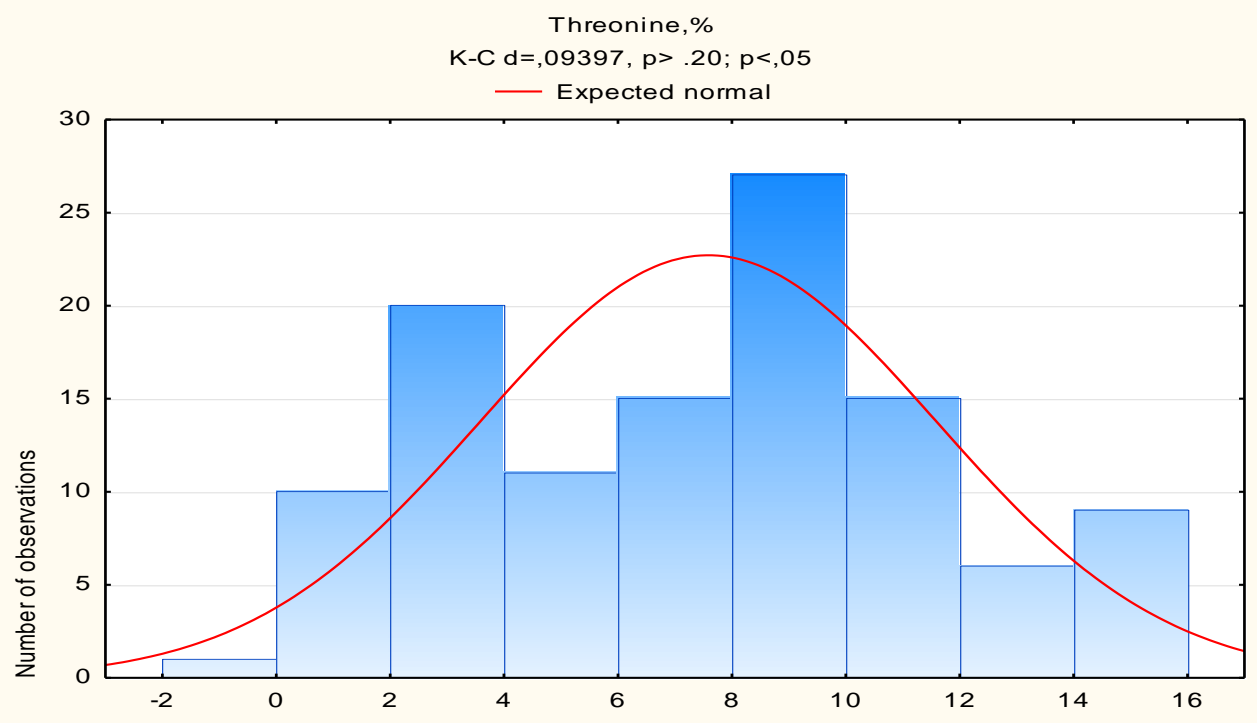

Fig. 4. Distribution samples by groups threonine content

\section{Conclusion}

As a result of studying the amino acid composition of domestic rice varieties, it was found that the maximum amount of amino acids in the studied rice varieties is proline $21.9 \%$, valine $11.5 \%$, serine $11.7 \%$, alanine $10.7 \%$, methionine $9.6 \%$, glycine $9,4 \%$. A wide inter 
varietal variation according to the trait has been established. Sources for the content of phenylalanine are varieties: Mulatka, Azov, Day / Night, Waterfall, Rain, Pearl, Svetlana, Zlata. The following varieties are characterized by a high content of methionine: Leader, Khazar, Kumir, Anahit, Mavr Olymp, Yuzhny, Courage, Svetlana, Dozhik; threonine: Birch, Waterfall, Gamma, Caprice, Svetlana, Sonnet. Sources high leucine content also highlighted: Favorit, Polevik, Flagman, Esaul, Zhemchuzhina.

This work was carried out with the financial support of the Russian Science Foundation No. 19-1600064.

\section{References}

1. H. Kobbekaduwa, A. Rita, F. Roberta, B. Remo, R. Mena, M. Flavio, Food Science of Technology Research, 15 (2009) DOI: https://doi.org/10.3136/fstr.15.507

2. L.L. Liu, H.Q. Zhai, J.M. Wan, Cereal Chemistry,82, 2 (2005)DOI: https://doi.org/10.1094/CC-82-0191

3. Yu.V. Fotev, V.F. Pivovarov, A.M. Artemyeva, I.M. Kulikov, Yu.K., Goncharova, A.I., Syso, N.P. Goncharov, Vavilov J. of Genetics and Breeding, 22, 7 (2018) DOI: https://doi.org/10.18699/VJ18.421.

4. L. Xie, N. Chen, B. Duan, Z. Zhu, X. Liao, J. of Cereal Science, 47, 2 (2008) DOI: https://doi.org/10.1016/j.jcs.2007.05.018

5. J.S. Kamara, S. Konishi, T. Sasanuma, T. Abe, Breed Sci.60 (2010) DOI: https://doi.org/10.1007/s42976-020-00125-x.

6. M. Martin, M. A. Fitzgerald, J. of Cereal Science, 36, 3 (2002) DOI: https://doi.org/10.1006/jcrs.2001.0465

7. K. Liu, J. Zheng, F. Chen, LWT Food Science and Technology, 82 (2017) DOI: https://doi.org/10.1016/j.lwt.2017.04.067.

8. A.O. Kasumyan, J. of Evolutionary Biochem. and Phys. 52 (2016) DOI: https://doi.org/10.1134/S0022093016040013

9. Yu.K. Goncharova, E.M. Kharitonov, N.Yu. Bushman, E.A. Malyuchenko Vavilov Journal of Genetics and Breeding, 22, 1 (2018) DOI: https://doi.org/10.18699/VJ18.334.

10. G.V.V. Liyanaarachchi, K.R.R. Mahanama, H.P.P.S. Somasiriet al, Cereal Research Communications, (2021)DOI:https://doi.org/10.1007/s42976-020-00125-x

11. T.Y. Curtis, N.G. Halford, Food and Energy Security,5 (2016) DOI: https://doi.org/10.1002/fes3.85

12. S. Zilic, D. Dodig, Z. Basic, J. Vancetovic, P. Titan, N. Duric, N. Tolimir, Food Additives and Contaminants, 34, 5 (2017) DOI: https://doi.org/10.1080/19440049.2017.1290281

13. http://www.fao.org/fao-who-codexalimentarius/s

14. R. Rambukwella, D. Priyadarshana, N. Wijesooriya, Research Report 204 (2017)

15. K. Inoue, T. Shirai, H.Ochiai, M.Kasao, K.Hayakawa,M. Kimura, H. Sansawa,European J. of Clinical Nutrition,57 (2003) DOI: https://doi.org/10.1038/sj.ejcn.1601555 ISO 712:2009.

16. B.G. Lyon, J.F. Meullenet, P. Marks, J.A. Hankins, K. Griffin et al, Cereal Chemistry. 76, 1 (1999) DOI: https://doi.org/10.1094/CCHEM.2000.77.2.259 